\title{
PENERAPAN METODE PROMETHEE II PADA DOSEN PENERIMA HIBAH P2M INTERNAL
}

\author{
Sri Rahayu Ningsih ${ }^{1}$, Agus Perdana Windarto ${ }^{2}$ \\ ${ }^{1,2}$ STIKOM Tunas Bangsa Pematangsiantar \\ 1,2 Jl. Jenderal Sudirman Blok A No.1-3 Pematangsiantar, Indonesia \\ srirahayuningsih1310@gmail.com,agus.perdana@amiktunasbangsa.ac.id
}

\begin{abstract}
Abstrak - Pengabdian Pada Masyarakat (P2M) merupakan salah satu bentuk aktivitas dosen dalam memberikan kontribusi secara langsung kepada masyarakat. Untuk mendukung dosen dalam pelaksanaan adalah adanya Program Hibah Pengabdian Internal. Program Pengabdian Hibah Internal dimaksudkan sebagai kegiatan pengabdian dalam rangka membina dan mengarahkan para dosen untuk meningkatkan kemampuannya dalam melaksanakan pengabdian di perguruan tinggi. Tujuan penelitian ini adalah menerapkan Preference Ranking Organization Method for Enrichment Evaluation (PROMETHEE II) dalam kasus Dosen Penerima Hibah Pengabdian Internal. Penilaian proposal Hibah P2M masih bersifat manual tanpa adanya sistem yang membantu para reviewer. Untuk mengatasi permasalahan tersebut diperlukan Sistem Pendukung Keputusan (SPK) yang diharapkan menyelesaikan permasalahan dalam pemberian Hibah P2M internal. Perbandingan analisa yang dilakukan hanya menjaga kualitas dari pengabdian pada masyarakat di lingkungan STIKOM Tunas Bangsa Pematangsiantar. Penerapan metode Promethee II diharapkan dapat membantu reviewer dalam menentukan calon dosen penerima Hibah P2M Internal.
\end{abstract}

Keywords-SPK, PROMETHEE II, Hibah.

\section{PENDAHULUAN}

Tri Dharma Perguruan Tinggi yaitu dharma pendidikan dan pengajaran, dharma penelitian dan dharma pengabdian kepada masyarakat, merupakan satu kesatuan yang utuh. Ketiga darma itu harus dilihat sebagai satu kesatuan yang saling terkait satu sama lain. Dalam implementasinya kegiatan dharma itu harus dilaksanakan secara sinergi sehingga sumbangan suatu perguruan tinggi terhadap kegiatan manusia dapat diwujudkan secara nyata. Oleh karena itu perkembangan perguruan tinggi harus diarahkan pada pengembangan ketiga bidang ini secara sinergi. LPPM STIKOM Tunas Bangsa Pematangsiantar merupakan lembaga yang menangani kegiatan bidang penelitian dan Pengabdian Pada Masyarakat (P2M) yang merupakan wadah bagi para dosen STIKOM Tunas Bangsa Pematangsiantar untuk mengembangkan pengetahuan yang dimiliki sesuai disiplin ilmu masing-masing melalui bidang pengabdian pada masyarakat. P2M merupakan salah satu bentuk aktivitas dosen dalam memberikan kontribusi secara langsung kepada masyarakat. Kegiatan ini biasa dilakukan dalam bentuk seminar, penyuluhan, bimbingan, konseling dan lain-lain.

Pengabdian kepada Masyarakat (PPM) adalah salah satu darma dari Tridarma Perguruan Tinggi yang wajib dilaksanakan oleh para dosen, namun demikian data dari Direktorat Penelitian dan Pengabdian kepada Masyarakat (Ditlitabmas) Direktorat Jenderal Pendidikan Tinggi, Kementerian Pendidikan dan Kebudayaan menunjukkan bahwa sampai dengan tahun 2010 kurang dari 5\% populasi dosen dan kurang dari $1 \%$ Guru Besar yang aktif melaksanakan PPM[1]. Dalam pelaksanaan pendidikan tinggi, penelitian dan pengabdian pada masyarakat masih dijadikan sebagai pekerjaan sampingan dosen selain belajar - mengajar seperti adanya program Hibah Internal. Program Pengabdian Hibah Internal dimaksudkan sebagai kegiatan pengabdian dalam rangka membina dan mengarahkan para dosen untuk meningkatkan kemampuannya dalam melaksanakan pengabdian di perguruan tinggi. Pengabdian pada masyarakat ini di peruntukkan bagi dosen yang belum bergelar doktor atau doktor dengan dana dari Hibah Internal perguruan tinggi. Jumlah dana yang dialokasikan untuk pengabdian pada masyarakat ini adalah Rp. 4.000.000,- s/d Rp. 5.000.000,untuk setiap judul pengabdian per semester dengan masa satu tahun 2 judul pengabdian. Diharapkan dari hasil pengabdian para dosen dapat dijadikan sebagai bahan pengayaan bagi para dosen dalam kegiatan pembelajaran. Dengan demikian dosen dapat menjalankan tridarma perguruan tinggi dengan optimal, karena telah mensinergikan antara kegiatan pembelajaran dengan pengabdian pada masyarakat. Dalam pelaksanaanya, Hibah P2M internal sering mengalami kendala. Ini bisa disebabkan oleh beberapa faktor. Salah satunya penilaian proposal masih bersifat manual tanpa adanya sistem yang membantu para reviewer. Untuk itu penulis membandingkan hasil dari penilaian reviewer dengan analisa menggunakan algoritma PROMETHEE II. Perbandingan analisa yang dilakukan hanya menjaga kualitas dari penelitian dan pengabdian di lingkungan STIKOM Tunas Bangsa Pematangsiantar. Banyak cabang ilmu komputer yang dapat menyelesaikan permasalahan yang bersifat kompleks. Hal ini 
terbukti dari penelitian terdahulu oleh para peneliti dalam menyelesaikan permasalahan[2][3] dalam bidang datamining, [4][5][6] dalam bidang jaringan saraf tiruan, [7][8] dalam bidang sistem pendukung keputusan. Berdasarkan penjelasan tersebut, peneliti menggunakan sistem pendukung keputusan untuk dapat menyelesaikan masalah diatas. Dalam hal ini peneliti mengambil salah satu metode yaitu metode PROMETHEE II[9], [10].

Penelitian sebelumnya yang berjudul Penerapan metode PROMETHEE II Pada sistem layanan dan rujukan Terpadu (SLRT). Metode PROMETHEE II adalah peringkat yang cukup sederhana dalam konsep dan aplikasi dibandingkan dengan metode lain untuk analisis multi kriteria. Metode ini nantinya akan pengambilan keputusan dengan beberapa kriteria yang saling bertentangan dan alternatif dan akan menghasilkan nilai terbesar yang nantinya terpilih sebagai alternatif terbaik[11]. Berdasarkan latar belakang diatas, Diharapkan dengan adanya algoritma PROMETHEE II ini dapat membantu kepada pihak yang terkait dalam menentukan rekomendasi dosen penerima Hibah Pengabdian pada Masyarakat Internal yang sesuai dengan hasil penilaian dari reviewer.

\section{TINJAUAN PUSTAKA}

\section{A. Sistem Pendukung Keputusan}

Sistem Pendukung Keputusan (SPK) adalah salah satu cara mengorganisir informasi yang dimaksudkan untuk digunakan dalam membuat keputusan[12]. Ada yang mendefinisikan bahwa system pendukung keputusan merupakan suatu pendekatan untuk mendukung pengambilan keputusan[13]. SPK bertujuan untuk menyuguhkan piranti interaktif yang memungkinkan pengambilan keputusan untuk menganalisa menggunakan model penyelesaian yang tersedia Sistem Pendukung Keputusan bukanlah alat penentu keputusan[14], [15]. SPK hanya membantu dalam pengambil keputusan dengan memberikan alternatif-alternatif terbaik berdasarkan hasil komputasi, dan untuk penentuan keputusan diserahkan sepenuhnya kepada pengguna. SPK hanya membantu memberikan hasil yang efektif dan efisien[14].

\section{B. Promethee II}

PROMETHEE merupakan salah satu dari metode Multi Criteria Decision Making (MCDM) yang berarti melakukan penentuan atau pengurutan dalam suatu analisis multikriteria, metode ini dikenal karena konsepnya yang efisien dan simple, selain itu untuk menyelesaikan masalah yang berhubungan dengan multikriteria, metode ini juga sangat mudah untuk diterapkan daripada metode lainnya. Metode PROMETHEE (preference ranking organization method for enrichment evaluation) dikembangkan oleh Brans dan Vincke pada tahun 1985. Metode PROMETHEE I dapat memberikan potongan parsial dari alternatif keputusan, sedangkan metode PROMETHEE II dapat memperoleh rangking keseluruhan dari alternatifnya. Dalam makalah ini, metode PROMETHEE II digunakan untuk mendapatkan rangking lengkap lokasi alternatif untuk aplikasi industri tertentu [16].

\section{Hibah}

Hibah adalah pemberian uang/barang atau jasa dari pemerintah daerah kepada pemerintah atau pemerintah daerah lainnya, perusahaan daerah, masyarakat dan organisasi kemasyarakatan, yang secara spesifik telah ditetapkan peruntukannya, bersifat tidak wajib dan tidak mengikat, serta tidak secara terus menerus yang bertujuan untuk menunjang penyelenggaraan urusn pemerintah daerah.

\section{METODOLOGI PENELITIAN}

PROMETHEE II digunakan untuk mendapatkan rangking lengkap lokasi alternatif untuk aplikasi industri tertentu. Langkah-langkah prosedural yang terlibat dalam metode PROMETHEE II terdaftar seperti di bawah ini :

Langkah 1: Menormalisasi matriks keputusan dengan menggunakan persamaan berikut:

$R_{i j}=\frac{\left.\llbracket x_{i j}-\min \left(x_{i j}\right)\right]}{\left.\llbracket \operatorname{Max}\left(x_{i j}\right)-\operatorname{Min}\left(x_{i j}\right)\right]}$

(i $=1,2, \ldots, n: j=1,2, \ldots, m)$

dimana Xij adalah ukuran kinerja dari alternatifnya sesuai kriteria jth. Untuk kriteria yang tidak menguntungkan, rumus (1) dapat ditulis ulang sebagai berikut:

$$
R_{i j}=\frac{\llbracket \max \left(x_{i j}\right)-x_{i j} \rrbracket}{\llbracket \operatorname{Max}\left(x_{i j}\right)-\operatorname{Min}\left(x_{i j}\right) \rrbracket}
$$

Langkah 2: Hitung perbedaan evaluatif dari alternatifnya sehubungan dengan alternatif lainnya. Langkah ini melibatkan perhitungan perbedaan dalam nilai-nilai kriteria antara berbagai alternatif pasangan-bijaksana.

\section{Langkah 3: Hitung fungsi preferensi, $\mathrm{Pj}\left(\mathrm{i}, \mathrm{i}^{\prime}\right)$.}

Ada terutama enam jenis fungsi preferensi umum seperti yang diusulkan oleh Brans dan Mareschal. Tetapi fungsi preferensi ini memerlukan definisi beberapa parameter preferensial, seperti preferensi dan ambang ketidakpedulian. Namun, dalam aplikasi waktu nyata, mungkin sulit bagi pengambil keputusan untuk menentukan bentuk spesifik fungsi preferensi yang sesuai untuk setiap kriteria dan juga untuk menentukan parameter yang terlibat. Untuk menghindari masalah ini, fungsi preferensi disederhanakan berikut diadopsi di sini:

$P_{j}\left(i, i^{\prime}\right)=0$ if $R_{i j} \leq R_{i^{\prime} j}$
$P_{j}\left(i, i^{\prime}\right)=\left(R_{i j}-R_{i^{\prime} j}\right) j i k a R_{i j}>R_{i^{\prime} j}$

Langkah 4: Hitung fungsi preferensi agregat dengan mempertimbangkan bobot kriteria. Fungsi preferensi gabungan

$\pi\left(\mathrm{i}, \mathrm{i}^{\prime}\right)=\frac{\left[\sum_{j-1}^{m} w_{j} \times \mathrm{P}_{j}\left(\mathrm{i}_{2} \mathrm{i}^{\prime}\right)\right]}{\sum_{j-1}^{m} w_{j}}$

dimana wj adalah kepentingan relatif (berat) dari kriteria jth.

Langkah 5: Tentukan arus keluar dan arus outranking sebagai berikut:

Meninggalkan (atau positif) mengalir untuk alternatif ini 


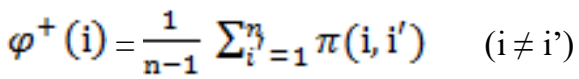

Memasuki (atau Negative) mengalir untuk alternatif ini

$$
\varphi^{-}(\mathrm{i})=\frac{1}{\mathrm{n}-1} \sum_{i=1}^{\eta^{3}} \pi\left(\mathrm{i}^{\prime}, \mathrm{i}\right) \quad\left(\mathrm{i} \neq \mathrm{i}^{\prime}\right)
$$

dimana $\mathrm{n}$ adalah jumlah alternatif.

Di sini, setiap alternatif wajah ( $\mathrm{n}$ - 1) jumlah alternatif lainnya. Aliran meninggalkan mengungkapkan berapa banyak alternatif yang mendominasi alternatif lain, sementara aliran masuk menunjukkan seberapa banyak alternatif didominasi oleh alternatif lain. Berdasarkan arus outranking ini, metode PROMETHEE I dapat memberikan beberapa preorder alternatif, sedangkan metode PROMETHEE II dapat memberikan preorder lengkap dengan menggunakan aliran net, meskipun kehilangan banyak informasi tentang hubungan preferensi.

Langkah 6: Hitung aliran mengungguli bersih untuk setiap alternatif.

$$
\varphi(i)=\varphi^{+} \text {(i) }-\varphi^{-} \text {(i) }
$$

Langkah 7: Tentukan rangking semua alternatif yang dipertimbangkan tergantung pada nilai $\varphi$ (i). Nilai yang lebih tinggi dari $\varphi$ (i), semakin baik alternatifnya. Dengan demikian, alternatif terbaik adalah yang memiliki nilai $\varphi$ (i) tertinggi.

Metode PROMETHEE adalah pendekatan pengambilan keputusan multi-kriteria interaktif yang dirancang untuk menangani kriteria kuantitatif serta kualitatif dengan alternatif diskrit. Dalam metode ini, perbandingan berpasangan dari alternatif dilakukan untuk menghitung fungsi preferensi untuk setiap kriteria. Berdasarkan fungsi preferensi ini, indeks preferensiuntuk alternatif $i$ atas i' ditentukan. Indeks preferensi ini adalah ukuran untuk mendukung hipotesis bahwa alternatif saya lebih disukai daripada i'. Metode PROMETHEE memiliki keunggulan signifikan dibandingkan pendekatan MCDM lainnya, mis. Multi attribute utility theory (MAUT) dan AHP. Metode PROMETHEE dapat mengklasifikasikan alternatif yang sulit untuk dibandingkan karena hubungan trade-off standar evaluasi sebagai alternatif yang tidak sebanding. Ini sangat berbeda dari AHP karena tidak perlu melakukan perbandingan berpasangan lagi ketika alternatif komparatif ditambahkan atau dihapus.

\section{HASIL DAN PEMBAHASAN}

1. Menentukan alternatif, yaitu Ai. Tabel 1 menampilkan nama-nama revisi calon penerima hibah yang telah di inisialkan yang pada akhir proses akan diranking dari yang paling layak sampai yang kurang layak.

$$
\text { TABEL } 1
$$

KANDIDAT CALON PENERIMA HIBAH

\begin{tabular}{|l|c|c|}
\hline No. & Alternatif & $\left(\mathrm{A}_{\mathrm{i}}\right)$ \\
\hline 1. & Dosen 1 & $\mathrm{~A} 1$ \\
\hline 2. & Dosen 2 & $\mathrm{~A} 2$ \\
\hline 3. & Dosen 3 & $\mathrm{~A} 3$ \\
\hline
\end{tabular}

\begin{tabular}{|l|l|l|}
\hline 4. & Dosen 4 & A4 \\
\hline 5. & Dosen 5 & A5 \\
\hline 6. & Dosen 6 & A6 \\
\hline 7. & Dosen 7 & A7 \\
\hline 8. & Dosen 8 & A8 \\
\hline 9. & Dosen 9 & A9 \\
\hline
\end{tabular}

2. Menentukan kriteria yang akan dijadikan acuan dalam pengambilan keputusan, yaitu $\mathrm{Cj}$. Kriteria yang ditetapkan berdasarkan form penilaian Hibah Internal dari reviewer,

\begin{tabular}{|c|c|c|c|}
\hline Kriteria & $\left(C_{j}\right)$ & Tipe & Bobot \\
\hline $\begin{array}{l}\text { Analisis Situasi (Kondisi } \\
\text { Mitra saat ini, Persoalan } \\
\text { umum yang dihadapi mitra) }\end{array}$ & $\mathrm{C} 1$ & Benefit & 20 \\
\hline $\begin{array}{l}\text { Permasalahan priorits Mitra } \\
\text { dan solusi yang ditawarkan } \\
\text { (Kecocokan permasalahan, } \\
\text { solusi dan kompetisi tim) }\end{array}$ & $\mathrm{C} 2$ & Benefit & 15 \\
\hline $\begin{array}{l}\text { Target Luaran (Jenis luaran } \\
\text { dan spesifikasinya sesuai } \\
\text { kegiatan yang diusulkan) }\end{array}$ & $\mathrm{C} 3$ & Benefit & 15 \\
\hline $\begin{array}{lr}\text { Ketepatan } & \text { Metode } \\
\text { Pendekatan untuk } & \text { mengatasi } \\
\text { permasalahan, } & \text { Rencana } \\
\text { kegiatan, } & \text { kontribusi } \\
\text { partisipasi mitra } & \\
\end{array}$ & $\mathrm{C} 4$ & Benefit & 20 \\
\hline $\begin{array}{l}\text { Kelayakan PT (Kualifikasi } \\
\text { Tim Pelaksana, Relevansi } \\
\text { Skill Tim, Sinergisme Tim, } \\
\text { Pengalaman } \\
\text { kemasyarakatan, Organisasi } \\
\text { Tim, Jadwal Kegiatan, } \\
\text { Kelengkapan Lampiran) }\end{array}$ & C5 & Benefit & 10 \\
\hline $\begin{array}{l}\text { Biaya Pekerjaan Kelayakan } \\
\text { Usulan Biaya ( } \\
\text { Honorarium (maksimum } \\
30 \% \text { ). Bahan habis, } \\
\text { Peralatan, Perjalanan, Lain- } \\
\text { lain pengeluaran) }\end{array}$ & C6 & Cost & 20 \\
\hline
\end{tabular}
seperti terlihat pada Tabel 2.

TABEL II

KRITERIA PENERIMA HIBAH

3. Tabel 3 adalah memberikan nilai setiap alternatif pada setiap kriteria. Untuk memberikan nilai alternatif pada setiap kriteria, maka ditentukan terlebih dahulu bobot setiap kriteria. Bobot 7 merupakan nilai tertinggi dan bobot 1 merupakan nilai terendah. Pemberian nilai bobot merupakan hasil wawancara kepada Reviewer.

$$
\text { TABEL III }
$$

TINGKAT KEPENTINGAN

\begin{tabular}{|c|c|c|}
\hline No. & Skor & Keterangan \\
\hline 1. & 1 & Buruk \\
\hline 2 & 2 & Sangat Kurang \\
\hline 3. & 3 & Kurang \\
\hline
\end{tabular}




\begin{tabular}{|c|c|c|}
\hline 4. & 5 & Cukup \\
\hline 5. & 6 & Baik \\
\hline 6. & 7 & Sangat Baik \\
\hline
\end{tabular}

4. Tabel 4 adalah alternatif yang telah diberikan nilai oleh Reviewer berdasarkan bobot kriteria yang telah ditentukan diatas.

TABEL IV

DATA PENILAIAN DARI REVIEWER

\begin{tabular}{|l|c|c|c|c|c|c|}
\hline Alternatif & C1 & C2 & C3 & C4 & C5 & C6 \\
\hline Dosen 1 & 3 & 7 & 6 & 5 & 5 & 5 \\
\hline Dosen 2 & 5 & 5 & 3 & 5 & 6 & 6 \\
\hline Dosen 3 & 5 & 6 & 6 & 3 & 5 & 5 \\
\hline Dosen 4 & 3 & 3 & 6 & 5 & 5 & 5 \\
\hline Dosen 5 & 5 & 5 & 5 & 5 & 3 & 5 \\
\hline Dosen 6 & 6 & 3 & 5 & 5 & 3 & 5 \\
\hline Dosen 7 & 5 & 3 & 5 & 3 & 5 & 5 \\
\hline Dosen 8 & 5 & 3 & 5 & 5 & 3 & 5 \\
\hline Dosen 9 & 6 & 3 & 5 & 3 & 3 & 3 \\
\hline
\end{tabular}

5. Tabel 4 adalah data yang masih merupakan skor dari reviewer. Dengan ketentuan yang tercantum pada form penilaian yang diberikan oleh reviewer bahwa nilai diperoleh dari Nilai $=\mathrm{W}($ bobot $) \mathrm{x}$ Skor, sehingga hasil dapat dilihat pada tabel 5 .

TABEL V

NILAI ALTERNATIF PADA SETIAP KRITERIA

\begin{tabular}{|l|c|c|c|c|c|c|}
\hline Alternatif & $\mathrm{C} 1$ & $\mathrm{C} 2$ & $\mathrm{C} 3$ & $\mathrm{C} 4$ & $\mathrm{C} 5$ & $\mathrm{C} 6$ \\
\hline Dosen 1 & 60 & 105 & 90 & 100 & 50 & 100 \\
\hline Dosen 2 & 100 & 75 & 45 & 100 & 60 & 120 \\
\hline Dosen 3 & 100 & 90 & 90 & 60 & 50 & 100 \\
\hline Dosen 4 & 60 & 45 & 90 & 100 & 50 & 100 \\
\hline Dosen 5 & 100 & 75 & 75 & 100 & 30 & 100 \\
\hline Dosen 6 & 120 & 45 & 75 & 100 & 30 & 100 \\
\hline Dosen 7 & 100 & 45 & 75 & 60 & 50 & 100 \\
\hline Dosen 8 & 100 & 45 & 75 & 100 & 30 & 100 \\
\hline Dosen 9 & 120 & 45 & 75 & 60 & 30 & 60 \\
\hline
\end{tabular}

6. Melakukan normalisasi matrik alternatif terhadap kriteria. Normalisasi didapatkan dengan menggunakan rumus (1) dan untuk kriteria yang tidak menguntungkan menggunakan rumus (2). Hasil matriks ternormalisasi terlihat pada Tabel 6 .

TABEL VI

MATRIKS NORMALISASI

\begin{tabular}{|l|c|c|c|c|c|c|}
\hline \multirow{2}{*}{ Alternatif } & \multicolumn{7}{|c|}{ Kriteria } \\
\cline { 2 - 7 } & C1 & C2 & C3 & C4 & C5 & C6 \\
\hline A1 & 0 & 1 & 1 & 1 & 0,67 & 0,33 \\
\hline A2 & 0,67 & 0,5 & 0 & 1 & 1 & 0 \\
\hline A3 & 0,67 & 0,75 & 1 & 0 & 0,67 & 0,33 \\
\hline A4 & 0 & 0 & 1 & 1 & 0,67 & 0,33 \\
\hline A5 & 0,67 & 0,5 & 0,67 & 1 & 0 & 0,33 \\
\hline A6 & 1 & 0 & 0,67 & 1 & 0 & 0,33 \\
\hline A7 & 0,67 & 0 & 0,67 & 0 & 0,67 & 0,33 \\
\hline
\end{tabular}

\begin{tabular}{|l|c|c|c|c|c|c|}
\hline A8 & 0,67 & 0 & 0,67 & 1 & 0 & 0,33 \\
\hline A9 & 1 & 0 & 0,67 & 0 & 0 & 1 \\
\hline
\end{tabular}

7. Hitung perbedaan evaluatif dari alternatifnya sehubungan dengan alternatif lainnya. Langkah ini melibatkan perhitungan perbedaan dalam nilai-nilai kriteria antara berbagai alternatif pasangan-bijaksana.

8. Selanjutnya, fungsi preferensi dihitung untuk semua pasangan alternatif. menggunakan rumus (3) dan rumus (4). Hasil yang diperoleh terlihat pada Tabel 7. TABEL VII

PREFERENSI UNTUK SEMUA PASANGAN ALTERNATIF

\begin{tabular}{|l|c|c|c|c|c|c|}
\hline A1,A2 & 0 & 0,5 & 1 & 0 & 0 & 0,333 \\
\hline A1,A3 & 0 & 0,25 & 0 & 1 & 0 & 0 \\
\hline A1,A4 & 0 & 1 & 0 & 0 & 0 & 0 \\
\hline A1,A5 & 0 & 0,5 & 0,33 & 0 & 0,67 & 0 \\
\hline A1,A6 & 0 & 1 & 0,33 & 0 & 0,67 & 0 \\
\hline A1,A7 & 0 & 1 & 0,33 & 1 & 0 & 0 \\
\hline A1,A8 & 0 & 1 & 0,33 & 0 & 0,67 & 0 \\
\hline A1,A9 & 0 & 1 & 0,33 & 1 & 0,67 & 0 \\
\hline A2,A1 & 0,67 & 0 & 0 & 0 & 0,33 & 0 \\
\hline A2,A3 & 0 & 0 & 0 & 1 & 0,33 & 0 \\
\hline A2,A4 & 0,67 & 0,5 & 0 & 0 & 0,33 & 0 \\
\hline A2,A5 & 0 & 0 & 0 & 0 & 1 & 0 \\
\hline A2,A6 & 0 & 0,5 & 0 & 0 & 1 & 0 \\
\hline A2,A7 & 0 & 0,5 & 0 & 1 & 0,33 & 0 \\
\hline A2,A8 & 0 & 0,5 & 0 & 0 & 1 & 0 \\
\hline A2,A9 & 0 & 0,5 & 0 & 1 & 1 & 0 \\
\hline A3,A1 & 0,67 & 0 & 0 & 0 & 0 & 0 \\
\hline A3,A2 & 0 & 0,25 & 1 & 0 & 0 & 0,33 \\
\hline A3,A4 & 0,67 & 0,75 & 0 & 0 & 0 & 0 \\
\hline A3,A5 & 0 & 0,25 & 0,33 & 0 & 0,67 & 0 \\
\hline A3,A6 & 0 & 0,75 & 0,33 & 0 & 0,67 & 0 \\
\hline A3,A7 & 0 & 0,75 & 0,33 & 0 & 0 & 0 \\
\hline A3,A8 & 0 & 0,75 & 0,33 & 0 & 0,67 & 0 \\
\hline A3,A9 & 0 & 0,75 & 0,33 & 0 & 0,67 & 0 \\
\hline A4,A1 & 0 & 0 & 0 & 0 & 0 & 0 \\
\hline A4,A2 & 0 & 0 & 1 & 0 & 0 & 0,33 \\
\hline A4,A3 & 0 & 0 & 0 & 1 & 0 & 0 \\
\hline A4,A5 & 0 & 0 & 0,33 & 0 & 0,67 & 0 \\
\hline A4,A6 & 0 & 0 & 0,33 & 0 & 0,67 & 0 \\
\hline A4,A7 & 0 & 0 & 0,33 & 1 & 0 & 0 \\
\hline A4,A8 & 0 & 0 & 0,33 & 0 & 0,67 & 0 \\
\hline A4,A9 & 0 & 0 & 0,33 & 1 & 0,67 & 0 \\
\hline A5,A1 & 0,67 & 0 & 0 & 0 & 0 & 0 \\
\hline A5,A2 & 0 & 0 & 0,67 & 0 & 0 & 0,33 \\
\hline A5,A3 & 0 & 0 & 0 & 1 & 0 & 0 \\
\hline A5,A4 & 0,67 & 0,5 & 0 & 0 & 0 & 0 \\
\hline A5,A6 & 0 & 0,5 & 0 & 0 & 0 & 0 \\
\hline
\end{tabular}




\begin{tabular}{|l|c|c|c|c|c|c|}
\hline A5,A7 & 0 & 0,5 & 0 & 1 & 0 & 0 \\
\hline A5,A8 & 0 & 0,5 & 0 & 0 & 0 & 0 \\
\hline A5,A9 & 0 & 0,5 & 0 & 1 & 0 & 0 \\
\hline A6,A1 & 1 & 0 & 0 & 0 & 0 & 0 \\
\hline A6,A2 & 0,33 & 0 & 0,67 & 0 & 0 & 0,33 \\
\hline A6,A3 & 0,33 & 0 & 0 & 1 & 0 & 0 \\
\hline A6,A4 & 1 & 0 & 0 & 0 & 0 & 0 \\
\hline A6,A5 & 0,33 & 0 & 0 & 0 & 0 & 0 \\
\hline A6,A7 & 0,33 & 0 & 0 & 1 & 0 & 0 \\
\hline A6,A8 & 0,33 & 0 & 0 & 0 & 0 & 0 \\
\hline A6,A9 & 0 & 0 & 0 & 1 & 0 & 0 \\
\hline A7,A1 & 0,67 & 0 & 0 & 0 & 0 & 0 \\
\hline A7,A2 & 0 & 0 & 0,67 & 0 & 0 & 0,33 \\
\hline A7,A3 & 0 & 0 & 0 & 0 & 0 & 0 \\
\hline A7,A4 & 0,67 & 0 & 0 & 0 & 0 & 0 \\
\hline A7,A5 & 0 & 0 & 0 & 0 & 0,67 & 0 \\
\hline A7,A6 & 0 & 0 & 0 & 0 & 0,67 & 0 \\
\hline A7,A8 & 0 & 0 & 0 & 0 & 0,67 & 0 \\
\hline A7,A9 & 0 & 0 & 0 & 0 & 0,67 & 0 \\
\hline A8,A1 & 0,67 & 0 & 0 & 0 & 0 & 0 \\
\hline A8,A2 & 0 & 0 & 0,67 & 0 & 0 & 0,33 \\
\hline A8,A3 & 0 & 0 & 0 & 1 & 0 & 0 \\
\hline A8,A4 & 0,67 & 0 & 0 & 0 & 0 & 0 \\
\hline A8,A5 & 0 & 0 & 0 & 0 & 0 & 0 \\
\hline A8,A6 & 0 & 0 & 0 & 0 & 0 & 0 \\
\hline A8,A7 & 0 & 0 & 0 & 1 & 0 & 0 \\
\hline A8,A9 & 0 & 0 & 0 & 1 & 0 & 0 \\
\hline A9,A1 & 1 & 0 & 0 & 0 & 0 & 0,67 \\
\hline A9,A2 & 0,33 & 0 & 0,67 & 0 & 0 & 1 \\
\hline A9,A3 & 0,33 & 0 & 0 & 0 & 0 & 0,67 \\
\hline A9,A4 & 1 & 0 & 0 & 0 & 0 & 0,67 \\
\hline A9,A5 & 0,33 & 0 & 0 & 0 & 0 & 0,67 \\
\hline A9,A6 & 0 & 0 & 0 & 0 & 0 & 0,67 \\
\hline A9,A7 & 0,33 & 0 & 0 & 0 & 0 & 0,67 \\
\hline A9,A8 & 0,33 & 0 & 0 & 0 & 0 & 0,67 \\
\hline & & & & & & \\
\hline
\end{tabular}

9. Hitung fungsi preferensi agregat dengan mempertimbangkan bobot kriteria. Tabel 8. menunjukkan nilai fungsi preferensi agregat untuk semua alternatif berpasangan, yang dihitung menggunakan rumus (5).

$$
\text { TABEL VIII }
$$

HASIL FUNGSI PREFERENSI GABUNGAN

\begin{tabular}{|c|c|c|c|c|c|c|c|c|c|}
\hline Alt & A1 & A2 & A3 & A4 & A5 & A6 & A7 & A8 & A9 \\
\hline A1 & - & $\begin{array}{l}22, \\
57\end{array}$ & $\begin{array}{l}23, \\
75\end{array}$ & 15 & $\begin{array}{l}19, \\
17\end{array}$ & $\begin{array}{l}26, \\
67\end{array}$ & 40 & $\begin{array}{l}26, \\
67 \\
\end{array}$ & $\begin{array}{r}46, \\
67 \\
\end{array}$ \\
\hline A2 & $\begin{array}{l}16, \\
67\end{array}$ & - & $\begin{array}{l}23, \\
33\end{array}$ & $\begin{array}{l}24, \\
17\end{array}$ & 10 & $\begin{array}{c}17, \\
5\end{array}$ & $\begin{array}{l}30, \\
83\end{array}$ & $\begin{array}{c}17, \\
5\end{array}$ & $\begin{array}{c}37, \\
5\end{array}$ \\
\hline A3 & $\begin{array}{l}13, \\
33\end{array}$ & $\begin{array}{l}18, \\
82\end{array}$ & - & $\begin{array}{l}24, \\
58\end{array}$ & $\begin{array}{l}15, \\
42\end{array}$ & $\begin{array}{l}22, \\
92\end{array}$ & $\begin{array}{l}16, \\
25\end{array}$ & $\begin{array}{l}22, \\
92\end{array}$ & $\begin{array}{l}22, \\
92\end{array}$ \\
\hline A4 & 0 & $\begin{array}{l}15, \\
07\end{array}$ & 20 & - & $\begin{array}{l}11, \\
67\end{array}$ & $\begin{array}{l}11, \\
67\end{array}$ & 25 & $\begin{array}{l}11, \\
67\end{array}$ & $\begin{array}{l}31, \\
67\end{array}$ \\
\hline A5 & $\begin{array}{l}13 \\
33\end{array}$ & 10 , & 20 & $\begin{array}{l}20, \\
83\end{array}$ & - & 7,5 & 27, & 7,5 & $\begin{array}{c}27, \\
5\end{array}$ \\
\hline
\end{tabular}

\begin{tabular}{|c|c|c|c|c|c|c|c|c|c|}
\hline A6 & 20 & $\begin{array}{c}16, \\
73\end{array}$ & $\begin{array}{c}26, \\
67\end{array}$ & 20 & $\begin{array}{c}6,6 \\
7\end{array}$ & - & $\begin{array}{c}26, \\
67\end{array}$ & $\begin{array}{c}6,6 \\
7\end{array}$ & 20 \\
\hline A7 & $\begin{array}{c}13, \\
33\end{array}$ & $\begin{array}{c}10, \\
07\end{array}$ & 0 & $\begin{array}{c}13, \\
33\end{array}$ & $\begin{array}{c}6,6 \\
7\end{array}$ & $\begin{array}{c}6,6 \\
7\end{array}$ & - & $\begin{array}{c}6,6 \\
7\end{array}$ & $\begin{array}{c}6,6 \\
7\end{array}$ \\
\hline A8 & $\begin{array}{c}13, \\
33\end{array}$ & $\begin{array}{c}10, \\
07\end{array}$ & 20 & $\begin{array}{c}13, \\
33\end{array}$ & 0 & 0 & 20 & - & 20 \\
\hline A9 & $\begin{array}{c}20, \\
13\end{array}$ & $\begin{array}{c}16, \\
87\end{array}$ & 6,8 & $\begin{array}{c}20, \\
13\end{array}$ & 6,8 & 0 & 6,8 & 6,8 & - \\
\hline
\end{tabular}

10. Tentukan arus keluar dan arus masuk Meninggalkan dan arus masuk untuk alternatif lokasi yang berbeda sekarang dihitung menggunakan Persamaan. (6) dan (7). Hasil ditunjukkan pada Tabel 9. TABEL IX

HASIL ARUS KELUAR DAN ARUS MASUK UNTUK ALTERNATIF YANG BERBEDA

\begin{tabular}{|l|c|c|}
\hline Alternatif & Leaving flow & Entering flow \\
\hline A1 & 27,56 & 13,77 \\
\hline A2 & 22,19 & 15,03 \\
\hline A3 & 19,64 & 17,57 \\
\hline A4 & 15,84 & 18,92 \\
\hline A5 & 16,78 & 9,55 \\
\hline A6 & 17,93 & 11,63 \\
\hline A7 & 7,93 & 24,13 \\
\hline A8 & 12,09 & 13,30 \\
\hline A9 & 10,56 & 26,61 \\
\hline
\end{tabular}

11. Hitung aliran mengungguli bersih untuk setiap alternatif dengan mengurangkan arus keluar dengan arus masuk menggunakan rumus (8). Hasil ditunjukkan pada Tabel 10 .

TABEL $X$ NILAI ALIRAN BERSIH

\begin{tabular}{|c|c|}
\hline Alternatif & Net flow \\
\hline A1 & 13,79 \\
\hline A2 & 7,16 \\
\hline A3 & 2,08 \\
\hline A4 & $-3,08$ \\
\hline A5 & 7,23 \\
\hline A6 & 6,29 \\
\hline A7 & $-16,21$ \\
\hline A8 & $-1,21$ \\
\hline A9 & $-16,06$ \\
\hline
\end{tabular}

12. Tentukan rangking semua alternatif yang dipertimbangkan tergantung nilai $\mathrm{A}_{\mathrm{x}}$. Hasil ditunjukkan pada Tabel 11 . TABEL XI

HASIL DARI OUTRANGKING BERSIH SETIAP ALTERNATIF

\begin{tabular}{|c|c|c|}
\hline Alternatif & Net flow & Ranking \\
\hline A1 & 13,79 & 1 \\
\hline A2 & 7,16 & 3 \\
\hline
\end{tabular}




\begin{tabular}{|c|c|c|}
\hline A3 & 2,08 & 5 \\
\hline A4 & $-3,08$ & 7 \\
\hline A5 & 7,23 & 2 \\
\hline A6 & 6,29 & 4 \\
\hline A7 & $-16,21$ & 9 \\
\hline A8 & $-1,21$ & 6 \\
\hline A9 & $-16,06$ & 8 \\
\hline
\end{tabular}

\section{KESIMPULAN}

Berdasarkan hasil dari pembahasan, bahwa sistem pendukung keputusan dengan algoritma PROMETHEE II dapat dijadikan solusi dari permasalahan menentukan dosen penerima hibah pengabdian Internal. Hasil perhitungan dari 9 Alternatif, maka dapat disimpulkan 5 alternatif yang sangat layak di usulkan sebagai dosen yang mendapatkan Hibah P2M Internal adalah A1, A5, A2, A6, A3 dengan nilai preferensi yang sama persis dengan penilaian reviewer. Ini membuktikan penerapan dan potensi dari metode PROMETHEE II untuk memecahkan masalah pembuatan keputusan yang rumit dalam memprioritaskan pusat pengumpulan. Dengan adanya sistem ini dapat dijadikan perbandingan antara penilai reviewer dengan sistem PROMETHEE II sehingga dapat menjaga kualitas penilaian dalam menentukan penerima hibah pengabdian internal secara objektif.

\section{REFERENSI}

[1] I. Danuwikarsa, "Peran Perguruan Tinggi Melalui Penelitian Dan Program Pengabdian Kepada Masyarakat Dalam Penanggulangan Bencana Di Indonesia," vol. 3, no. 1, pp. 1-14, 2013.

[2] A. P. Windarto, "Penerapan Data Mining Pada Ekspor BuahBuahan Menurut Negara Tujuan Menggunakan K-Means Clustering," Techno.COM, vol. 16, no. 4, pp. 348-357, 2017.

[3] M. G. Sadewo, A. P. Windarto, and D. Hartama, "Penerapan Datamining Pada Populasi Daging Ayam Ras Pedaging Di Indonesia Berdasarkan Provinsi Menggunakan K-Means Clustering," InfoTekJar (Jurnal Nas. Inform. dan Teknol. Jaringan), vol. 2, no. 1, pp. 60-67, 2017.

[4] Sumijan, A. P. Windarto, A. Muhammad, and Budiharjo, "Implementation of Neural Networks in Predicting the Understanding Level of Students Subject," Int. J. Softw. Eng. Its Appl., vol. 10, no. 10, pp. 189-204, 2016.

[5] M. N. H. Siregar, "Neural Network Analysis With Backpropogation In Predicting Human Development Index (HDI) Component by Regency / City In North Sumatera," In te r $n$ a t i o n a l Jo u r $n$ a l Of Informatio $n$ S yst e m Te c h no logy, vol. 1, no. 1, pp. 22-33, 2017

[6] A. P. Windarto, L. S. Dewi, and D. Hartama, "Implementation of Artificial Intelligence in Predicting the Value of Indonesian Oil and Gas Exports With BP Algorithm," Int. J. Recent Trends Eng. Res. vol. 3, no. 10, pp. 1-12, 2017.

[7] A. Putrama and A. P. Windarto, "Analisis dalam menentukan produk bri syariah terbaik berdasarkan dana pihak ketiga menggunakan ahp," CESS (Journal Comput. Eng. Syst. Sci., vol. 3 , no. 1, pp. 60-64, 2018.

[8] P. P. P. A. N. W. F. I. R. H. Zer and A. P. Windarto, "Analisis Pemilihan Rekomendasi Produk Terbaik Prudential Berdasarkan Jenis Asuransi Jiwa Berjangka Untuk Kecelakaan Menggunakan Metode Analytic Hierarchy Process (AHP)," CESS (Journal Comput. Eng. Syst. Sci., vol. 3, no. 1, pp. 78-82, 2018.
Promethee II Pada Faktor Penyebab Mahasiswa Sulit Menemukan Judul Artikel Ilmiah," J. Ilm. KOMPUTASI, vol. 17, no. 2, pp. 131$135,2018$.

[10] T. Novika, A. Widiastari, V. Miralda, and A. P. Windarto, "SPK: Analisa Rekomendasi Bank Konvensional Dengan Promethee Sebagai Solusi Cerdas Untuk Menabung," JUSIM, vol. 3, no. 1, pp. $38-45,2018$

[11] I. Saputra and M. Ariska, "Penerapan Metode Promethee Ii Pada Sistem Layanan Dan Rujukan Terpadu (SLRT) (Studi Kasus : Dinas Sosial Kabupaten Deli Serdang)," vol. I, pp. 276-285, 2017.

[12] S. R. Ningsih, I. S. Damanik, I. Gunawan, and W. Saputra, "Electre Dalam Menentukan Penerima Program Indonesia Pintar (PIP) Melalui Kartu Indonesia Pintar (KIP) (Studi Kasus : SD Swasta A - Washliyah Moho Kabupaten Simalungun )," vol. I, pp. 264-275, 2017.

[13] S. Sundari et al., "Sistem Pendukung Keputusan Dengan Menggunakan Metode Electre Dalam Merekomendasikan Dosen Berprestasi Bidang Ilmu Komputer (Study Kasus di AMIK \& STIKOM Tunas Bangsa )," no. x, pp. 1-6, 2017.

[14] Agus Perdana Windarto, "Implementasi metode topsis dan saw dalam memberikan reward pelanggan," Kитрul. J. Ilти Котриt. vol. 4, no. 1, pp. 88-101, 2017.

[15] T. Imandasari and A. P. Windarto, "Sistem Pendukung Keputusan dalam Merekomendasikan Unit Terbaik di PDAM Tirta Lihou Menggunakan Metode Promethee," J. Teknol. dan Sist. Komput. vol. 5 , no. 4 , p. 159,2017

[16] N. Arunkumar et al., "Facility Layout Selection For The Blood Inventory Using PROMETHEE II Method,” vol. 2, no. August, pp. $1161-1166,2012$ 